\title{
Effect of Low Dose Dopamine on Hemodynamic and Renal Function in Children
}

\author{
E. GIRARDIN, M. BERNER, J. C. ROUGE, R. W. RIVEST, B. FRIEDLI, AND L. PAUNIER \\ Department of Paediatrics and Genetics [E.G., M.B., J.C.R., B.F., L.P.]; and Division of Endocrinology [R.W.R.] \\ Department of Medicine, Hôpital Cantonal Universitaire de Genève, 1211 Genève 4, Switzerland
}

\begin{abstract}
The purpose of the study was to investigate the effect of low doses of dopamine in children. Fourteen cases were studied after open heart surgery. Cardiac output and renal parameters were determined under baseline conditions and under continuous infusion of dopamine 2.5 and $5 \mu \mathrm{g} / \mathrm{kg} / \mathrm{min}$. During the control period cardiac index was $2.62 \pm 0.19 \mathrm{~L} / \mathrm{min} / \mathrm{m}^{2}$, renal plasma flow was decreased at $269 \pm 41 \mathrm{~mL} / \mathrm{min} / 1.73 \mathrm{~m}^{2}$, GFR was $86.6 \pm 9.2 \mathrm{~mL} / \mathrm{min} /$ $1.73 \mathrm{~m}^{2}$, and filtration fraction was elevated at $37.1 \pm$ $1.9 \%$. Plasma concentration of aldosterone correlated with the filtration fraction. At $5 \mu \mathrm{g} / \mathrm{kg} / \mathrm{min}$ dopamine increased significantly cardiac output, renal plasma flow, and to a lesser extent GFR, thus decreasing the filtration fraction. At $2.5 \mu \mathrm{g} / \mathrm{kg} / \mathrm{min}$ dopamine, increased renal plasma flow only in patients older than $5 \mathrm{y}$ and had no effect on the other parameters. The increase of cardiac output in response to dopamine was abolished by propanolol pretreatment. By contrast, the hemodynamic renal response to dopamine was not altered by $\beta$-blockade. These results indicate that $5 \mu \mathrm{g} / \mathrm{kg} / \mathrm{min}$ of dopamine could prevent renal failure after open heart surgery in children by increasing renal blood flow and attenuating renal compensatory mechanisms. (Pediatr Res 26:200-203, 1989)
\end{abstract}

\section{Abbreviation}

PAH, para-aminohippurate

In the presence of reduced cardiac output, dopamine is frequently used for both its positive cardiac inotropic and its renal vasodilatory effects. A considerable amount of data supports its use in adults (1-5) but hemodynamic and renal effect of dopamine have not yet been assessed in children. Some animal (6-8) and clinical studies (9) suggest that differences in response to dopamine exist between adults and pediatric patients.

After open heart surgery, cardiac output and systemic pressure are often depressed. Renal failure develops in 3 to $20 \%$ of patients depending on the criteria used and the patient population. It markedly influences the ultimate prognosis $(10-15)$.

Our study was designed to test the effect of a continuous infusion of dopamine, 2.5 and $5.0 \mu \mathrm{g} / \mathrm{kg} / \mathrm{min}$, on hemodynamic and renal function in children after open heart surgery.

\section{PATIENTS AND METHODS}

Patients. A total of 14 children were randomly selected from patients who underwent open heart surgery and had normal

Received December 30, 1988; accepted May 10, 1989.

Reprint request to Dr. E. Girardin, Department of Pediatrics and Genetics, Hôpital Cantonal Universitaire de Genève, 1211 Genève 4, Switzerland.

Supported by the Fondation Centre de Recherches Médicales Carlos et Elsie de Reuter and by the Swiss National Science Foundation Grant 3.495-086. renal function before the operation. The group consisted of eight girls and six boys aged 18 mo to $15 \mathrm{y}$. The clinical characteristics and the preoperative plasma creatinine concentrations are given in Table I. All the patients had normal urinalysis with negative or trace proteinuria. Before the operation, six children with tetralogy of Fallot were treated with 1 to $4 \mathrm{mg} / \mathrm{kg} /$ day of propranolol to prevent hypoxic spells; the drug was stopped $8 \mathrm{~h}$ before the beginning of the operation. The surgery was performed with cardiopulmonary bypass, deep hypothermia $\left(18\right.$ to $\left.24^{\circ} \mathrm{C}\right)$, and moderate hemodilution (20 to $30 \%$ ).

Cold chemical cardioplegia was used to obtain asystole. When cardiopulmonary bypass was discontinued, blood was infused until the left atrial pressure reached 9.5 to $12.5 \mathrm{~mm} \mathrm{Hg}$, and a single dose of furosemide $(1 \mathrm{mg} / \mathrm{kg})$ was given.

Method. After the operation, a Swan-Ganz catheter ( 5 Fr) was placed into the pulmonary artery. During the study, a solution containing $5 \%$ glucose and $\mathrm{NaCl}$ and $\mathrm{KCl}(2 \mathrm{mEq} / \mathrm{kg} / 24 \mathrm{~h})$ was infused at a rate of $750 \mathrm{~mL} / \mathrm{m}^{2} / 24 \mathrm{~h}$. The patient was ventilated with a volume controlled ventilator to maintain arterial carbon dioxide tension between 4.5 and $5.5 \mathrm{kPa}$ and sedated with a continuous infusion of morphine sulfate $(0.1 \mathrm{mg} / \mathrm{kg} / \mathrm{h})$. Cold solution of $5 \%$ glucose was injected through the proximal port of a Swan-Ganz catheter (American Edwards Laboratories, Santa Ana, CA). Patients weighing $<20 \mathrm{~kg}$ received $3.5 \mathrm{~mL}$, those more than $20 \mathrm{~kg} 5 \mathrm{~mL}$. Cardiac output was determined with a Kimray $3500 \mathrm{E}$ thermodilution computer (K.M.A. Inc., Oklahoma City, $\mathrm{OK}$ ), by averaging three consecutive measurements. Simultaneously, heart rate, systemic arterial pressure, central venous pressure, and left atrial pressure were measured through lines placed at surgery. Vascular pressures were measured with HewlettPackard pressure modules 78353B, (Hewlett-Packard Co., Palo Alto, CA), zero level positioned at mixthorax.

GFR and effective renal plasma flow were determined by the clearances of inulin (Laevosan AG, Zürich, Switzerland) and para-aminohippurate (PAH) (BAG, Hessen). A priming dose of $\mathrm{PAH}(8 \mathrm{mg} / \mathrm{kg})$ and inulin $(50 \mathrm{mg} / \mathrm{kg})$ was followed by a continuous infusion in order to achieve plasma concentration of 20 $\mathrm{mg} / \mathrm{L}$ for $\mathrm{PAH}$ and $200 \mathrm{mg} / \mathrm{L}$ for inulin. After an equilibration period of $1 \mathrm{~h}$, six 30-min urine collections were performed through an intravesical Foley catheter. Blood samples were obtained at the beginning and end of each collection period. PAH and inulin were analyzed by colorimetric techniques $(16,17)$. The clearance of PAH was corrected assuming a PAH extraction of 0.9 (18). Renal blood flow was calculated by dividing PAH clearance by 1-hematocrit. The renal fraction of total cardiac output was calculated by dividing the renal blood flow per $\mathrm{m}^{2}$ of body surface area by cardiac index. Fractional excretion of sodium and filtration fraction were calculated using standard formula. Aldosterone plasma concentrations were measured by RIA (Diagnostic Prod. Co., Los Angeles, CA; kit TKAL).

The study started 3 to $4 \mathrm{~h}$ after the end of anesthesia; the patient was in stable condition. A first set of measurements was made without dopamine infusion and served as a control. Do- 
pamine was then infused at 2.5 and $5.0 \mu \mathrm{g} / \mathrm{kg} / \mathrm{min}$, the doses being randomly alternated. Each of the three periods lasted $1 \mathrm{~h}$; the results of the two 30 min clearances within each period were averaged and hemodynamic measurement were performed 45 min after the beginning of the period. During the study, the patients did not receive any other medication. The study protocol was approved by the ethics committee of the pediatric department.

Statistical analysis. Two-way ANOVA was used to test the effect of dopamine at various dose levels. When the $F$ values were significant, the effect of each dose versus control was evaluated using the Newman-Keuls test. Correlations between two variables were analyzed by the nonparametric Spearman test and by linear least square regression. Values with and without preoperative propranolol treatment were compared by Student's $t$ test.

\section{RESULTS}

Control period. During the control period, renal plasma flow was $269 \pm 41 \mathrm{~mL} / \mathrm{min} / 1.73 \mathrm{~m}^{2}$, compared to normal values for the age $\left[1-3\right.$ y: $537 \pm 122 \mathrm{~mL} / \mathrm{min} / \mathrm{m}^{2} ; 3-8$ y: $659 \pm 115 ; 8-14$ $y: 631 \pm 98(19)]$. Cardiac index was comparatively preserved at $2.62 \pm 0.19 \mathrm{~L} / \mathrm{min} / \mathrm{m}^{2}$, so the fraction of the cardiac output delivered to the kidney, $10.0 \pm 1.2 \%$, was markedly decreased. GFR was $86.6 \pm 9.2 \mathrm{~mL} / \mathrm{min} / 1.73 \mathrm{~m}^{2}$, resulting in a high filtration fraction of $37.1 \pm 2.9 \%$ (Table 2 ). Renal blood flow was strongly related to mean systemic blood pressure $(p<0.01)$

Table 1. Clinical characteristics and preoperative plasma creatinine concentrations*

\begin{tabular}{|c|c|c|c|}
\hline Age (y mo) & Diagnosis & Operation & $\begin{array}{c}\text { Plasma } \\
\text { creatinine } \\
\text { (mmol/L) }\end{array}$ \\
\hline $1^{6 / 12}$ & $\mathrm{~T}-\mathrm{F}$ & $\operatorname{ccs}$ & 54 \\
\hline $1^{10 / 12}$ & $\mathrm{~T}-\mathrm{F}$ & $\operatorname{ccs}$ & 58 \\
\hline $2^{2 / 12}$ & VSD & Patch & 31 \\
\hline $2^{3 / 12}$ & $\mathrm{~T}-\mathrm{F}$ & $\operatorname{ccs}$ & 42 \\
\hline $3^{4 / 12}$ & $\mathrm{~T}-\mathrm{F}$ & $\operatorname{ccs}$ & 48 \\
\hline $3^{5 / 12}$ & $\mathrm{~T}-\mathrm{F}$ & $\operatorname{ccs}$ & 48 \\
\hline $3^{10 / 12}$ & $\mathrm{~T}-\mathrm{F}$ & $\operatorname{ccs}$ & 52 \\
\hline $7^{4 / 12}$ & $\mathrm{~T}-\mathrm{F}$ & $\operatorname{ccs}$ & 56 \\
\hline $9^{2 / 12}$ & Aortic stenosis & Aortotomy & 43 \\
\hline $10^{6 / 12}$ & Mitral insufficiency & Valvuloplasty & 50 \\
\hline $12^{2 / 12}$ & Mitral insufficiency & Valvuloplasty & 46 \\
\hline $12^{5 / 12}$ & $\begin{array}{l}\text { Partial atrioventric- } \\
\text { ular defect }\end{array}$ & Dacron patch & 50 \\
\hline $14^{5 / 12}$ & Mitral sufficiency & Valvuloplasty & 49 \\
\hline 15 & $\mathrm{~T}-\mathrm{F}$ & $\operatorname{ccs}$ & 59 \\
\hline
\end{tabular}

* T-F, tetralogy of Fallot; VSD, ventricular septal defect, ccs, complete corrective surgery: patch for VSD and infundibular enlargement.
(Fig. 1) but did not correlate with cardiac output. GFR showed a statistically significant correlation with the renal fraction of cardiac output $(p<0.05)$ (Fig. 2). Eleven of the 14 subjects had plasma aldosterone concentrations higher than the upper confidence limit for the age (20). The mean value was $3.62 \pm 1.27$ $\mathrm{mmol} / \mathrm{L}$. These circulating aldosterone levels correlated significantly with the filtration fraction $(p<0.005)$ (Fig. 3).

Effect of dopamine. At $2.5 \mu \mathrm{g} / \mathrm{kg} / \mathrm{min}$, dopamine did not increase the cardiac index, GFR, the renal fraction, or the urinary sodium excretion. The filtration fraction decreased to $32.8 \pm 3.0$ $(p<0.05)$. The heart rate, mean systemic pressure, and left atrial pressure also remained unchanged (Table 2). The renal plasma flow increased slightly in the group as a whole; however, the rise was significant only in the subgroup of seven patients older than $5 \mathrm{y}(p<0.05)$.

For the whole group, at $5.0 \mu \mathrm{g} / \mathrm{kg} / \mathrm{min}$, dopamine increased the cardiac output, the renal plasma flow, the GFR, and the urinary sodium excretion, whereas it decreased the filtration fraction. The heart rate and the mean systemic pressure remained unchanged. Left atrial pressure decreased compared to the control period (Table 2). Figure 4 describes the percent change of the hemodynamic and renal parameters in response to 2.5 and $5.0 \mu \mathrm{g} / \mathrm{kg} / \mathrm{min}$ of dopamine. Dopamine treatment did not modify significantly plasma aldosterone levels that averaged $3.30 \pm$ 1.11 and $3.77 \pm 1.26 \mathrm{mmol} / \mathrm{L}$ with 2.5 and $5.0 \mu \mathrm{g} / \mathrm{kg} / \mathrm{min}$ of dopamine, respectively.

Preoperative treatment with propranolol. During the control period cardiac index was similar in two subgroups of patients, one treated preoperatively with propranolol and the other not $\left(2.76 \pm 0.27\right.$ versus $\left.2.52 \pm 0.28 \mathrm{~L} / \mathrm{min} / \mathrm{m}^{2}\right)$. The effect of 5.0 $\mu \mathrm{g} / \mathrm{kg} / \mathrm{min}$ of dopamine was abolished by propranolol pretreatment: the increase of the cardiac index after dopamine was $1.5 \%$ in the propranolol-treated group and $26.4 \%$ in the untreated group $(p<0.02)$. Figure 5 compares the effect of $5.0 \mu \mathrm{g} / \mathrm{kg} / \mathrm{min}$ of dopamine on the cardiac index, renal plasma flow, and urinary

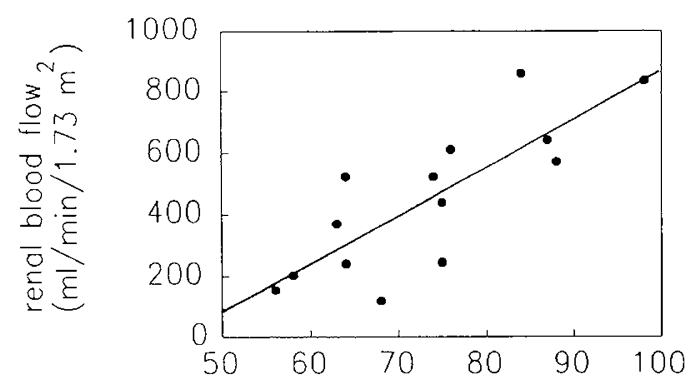

$$
\text { mean systemic pressure }(\mathrm{mmHg})
$$

Fig. 1. Correlation between mean systemic pressure and renal blood flow $(r=0.81, p<0.001)$.

Table 2. Hemodynamic and renal parameters after open heart surgery (mean \pm SEM)

\begin{tabular}{lccc}
\hline \multicolumn{1}{c}{ Parameter } & \multicolumn{3}{c}{ Dopamine $(\mu \mathrm{g} / \mathrm{kg} / \mathrm{min})$} \\
\cline { 2 - 4 } & 0 & 2.5 & $103.4 \pm 7.0^{* a+}$ \\
GFR $\left(\mathrm{mL} / \mathrm{min} / 1.73 \mathrm{~m}^{2}\right)$ & $86.6 \pm 9.2$ & $89.0 \pm 12.4$ & $406.3 \pm 61.0^{* c+}$ \\
Renal plasma flow $\left(\mathrm{mL} / \mathrm{min} / 1.73 \mathrm{~m}^{2}\right)$ & $269.2 \pm 41$ & $320.0 \pm 55.7$ & $29.8 \pm 2.5^{* c}$ \\
Filtration fraction $(\%)$ & $37.1 \pm 2.9$ & $32.8 \pm 3.0^{* a}$ & $0.33 \pm 0.08^{* b+}$ \\
Urinary sodium excretion $(\mathrm{mmol} / \mathrm{kg} / \mathrm{h})$ & $0.18 \pm 0.04$ & $0.23 \pm 0.06$ & $2.96 \pm 0.17^{* c+}$ \\
Cardiac index $\left(\mathrm{L} / \mathrm{min} / \mathrm{m}^{2}\right)$ & $2.62 \pm 0.19$ & $2.75 \pm 0.19$ & $13.0 \pm 1.3^{* b+}$ \\
Renal fraction $(\%)$ & $10.0 \pm 1.2$ & $11.1 \pm 1.5$ & $109 \pm 6$ \\
Heart rate (beats/min) & $106 \pm 6$ & $107 \pm 6$ & $73.8 \pm 2.5$ \\
Mean systemic pressure $(\mathrm{mm} \mathrm{Hg})$ & $73.6 \pm 3.3$ & $65.3 \pm 4.8$ & $9.9 \pm 1.0^{* a}$ \\
Left atrial pressure $(\mathrm{mm} \mathrm{Hg})$ & $11.7 \pm 0.9$ & $10.1 \pm 0.9$ & \\
\hline
\end{tabular}

\footnotetext{
${ }^{*} p$ compared to control period, ${ }^{a}<0.05 ;{ }^{b}<0.01 ;{ }^{c}<0.001$.

${ }^{+} p \leq 0.05$ for values compared to dopamine $2.5 \mu \mathrm{g} / \mathrm{kg} / \mathrm{min}$.
} 


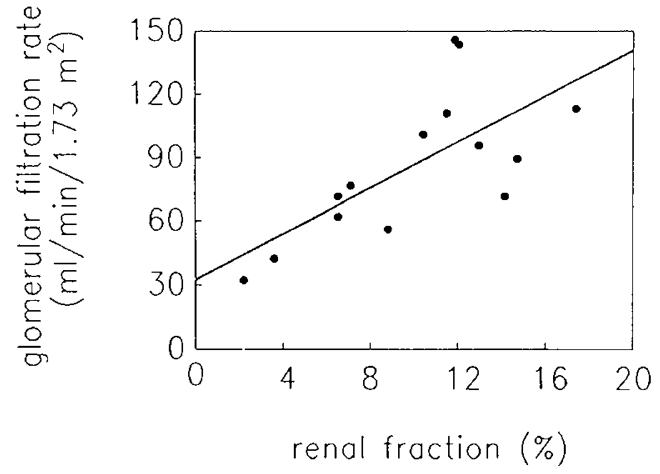

Fig. 2. Correlation between the renal fraction of cardiac output and $\operatorname{GFR}(r=0.69, p<0.01)$.

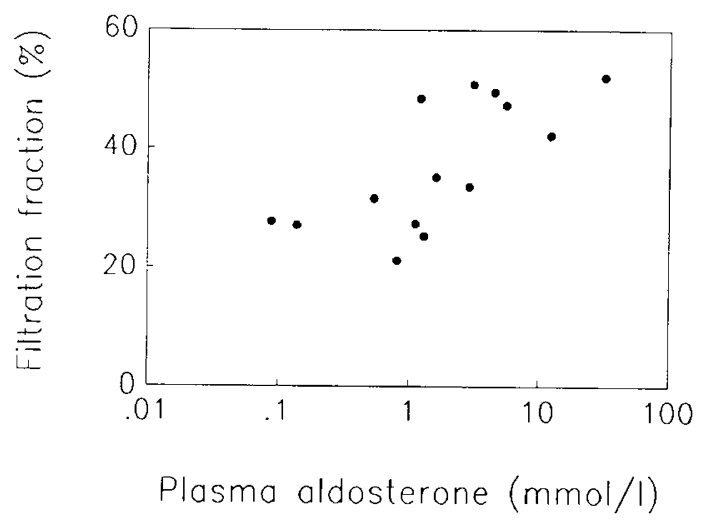

Fig. 3. Correlation between the logarithm of plasma aldosterone concentrations and filtration fraction $(r=0.70, p<0.005)$.

sodium excretion in the group of patients treated preoperatively with propranolol and in the untreated group. The effect of dopamine on renal plasma flow and urinary sodium excretion was not altered by propranolol pretreatment.

\section{DISCUSSION}

The results of our study demonstrate that compensatory mechanisms are involved to maintain normal renal function in the presence of borderline cardiac output after open heart surgery in children. Dopamine, as a $5.0 \mu \mathrm{g} / \mathrm{kg} / \mathrm{min}$ continuous infusion, improves renal blood flow and GFR. This reduces the filtration fraction and thus restores some degree of "functional renal reserve."

The striking feature in our patients, 3 to $4 \mathrm{~h}$ after completion of cardiopulmonary bypass, was their reduced renal blood flow as assessed by the PAH clearance method. PAH is an accurate measure of renal plasma flow providing that the extraction ratio of PAH is stable and reproducible under the experimental conditions. PAH extraction has been found to average $90.4 \% \pm 1.7$ in children over a wide age range (18). Previous studies have shown that PAH extraction decreases during the hypothermic period of open heart surgery but returns to preoperative values immediately after surgery, as soon as the patient's temperature is normal (21).

The reduction in renal plasma flow in our patients, with only a moderate decrease in cardiac output, indicates renal vasoconstriction. GFR is preserved at the expense of a high filtration fraction, induced by postglomerular vasoconstriction. This compensatory mechanism allows maximum GFR for the available renal blood flow and correlates in an animal model with high endogenous levels of angiotensin II (22). We measured high levels of circulating aldosterone, which were positively correlated to the filtration fraction. This is further evidence of the impor-

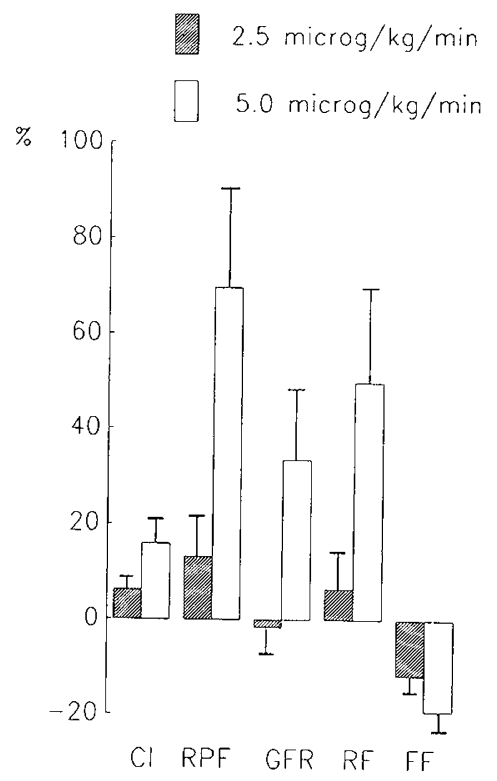

Fig. 4. Effect of 2.5 and $5.0 \mu \mathrm{g} / \mathrm{kg} / \mathrm{min}$ of dopamine on hemodynamic and renal parameters. Values are expressed as percent changes \pm SEM compared to control period. $C I$, cardiac index; $R P F$, renal plasma flow; $R F$, renal fraction of cardiac output; $F F$, filtration fraction.

Without propanolol

With propanolol
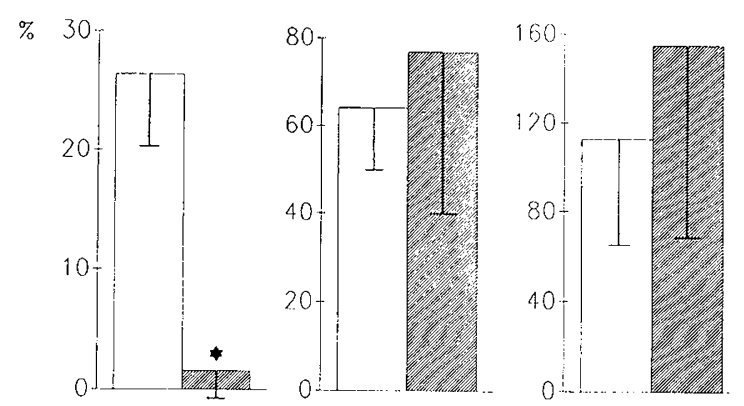

cardioc index

renal plosmo flow

urinory sodium

Fig. 5. Effect of $5.0 \mu \mathrm{g} / \mathrm{kg} / \mathrm{min}$ of dopamine between patients treated preoperatively with propranolol and those untreated. Values are expressed as percent changes compared to control period ${ }^{*} \mathrm{p}<0.02$.

tance of the angiotensin-aldosterone system in the preservation of GFR, when renal blood flow is decreased. Renal blood flow did not correlate with cardiac index, whereas it did with systemic arterial pressure; the GFR also correlated with the renal fraction of cardiac output. This underlines the critical importance of blood pressure over blood flow to maintain adequate renal blood flow in the immediate postoperative period and stresses the importance of the renal resistance in maintaining adequate renal function.

Dopamine at $5.0 \mu \mathrm{g} / \mathrm{kg} / \mathrm{min}$ has cardiac and renal effects. Cardiac output increases and left atrial pressure decreases, whereas heart rate and systemic vascular resistance are unchanged, indicating a true inotropic action of dopamine at this dosage. At the same time, renal blood flow, GFR, and urinary sodium excretion are significantly enhanced along with a reduction in filtration fraction. This suggests more pronounced precompared to postglomerular vasodilation and indicates that compensatory mechanisms are attenuated. Inhibitory modulation of aldosterone release by dopamine has been recently suggested. 
Metoclopramide induced secretion of aldosterone in man is reduced by concomitant infusion of dopamine $(23,24)$. However, as in our study, infusion of dopamine alone did not significantly affect aldosterone concentrations (23).

The renal effects of dopamine were identical in children who received propranolol preoperatively and those who did not. By contrast, the increase in cardiac output was abolished in those patients receiving propranolol preoperatively. This confirms the participation of the $\beta$-adrenergic receptors in this cardiac action of dopamine. Although the $t_{1 / 2}$ of propranolol is $4 \mathrm{~h}$, its effect on the receptors has been found to be more prolonged (25). This underlines also that the renal effects of dopamine are not secondary to the improvement in cardiac function and are most likely mediated by the activation of the $\delta$-receptors previously described $(26,27)$.

Analyzing the results of the whole group of children, dopamine at $2.5 \mu \mathrm{g} / \mathrm{kg} / \mathrm{min}$ had no effect on cardiac functions and only a moderate effect on renal functions (slight reduction of filtration fraction). The lack of effects of dopamine at this dosage in children after cardiac surgery contrasts with report on adults (3, 4). Interestingly, the renal response to low-dose dopamine is age dependent in animals. This is interpreted as a maturation process of renal dopamine receptors (6-8). However, premature neonates with respiratory distress syndrome receiving $2 \mu \mathrm{g} / \mathrm{kg} / \mathrm{min}$ of dopamine increased their natriuresis compared to a matched control group not treated by dopamine (28). In our study, some age dependency of the response to dopamine at $2.5 \mu \mathrm{g} / \mathrm{kg} / \mathrm{min}$ is suggested by a significantly greater increase in renal plasma flow in children older than $5 \mathrm{y}$.

In conclusion, continuous infusion of dopamine at $5.0 \mu \mathrm{g} / \mathrm{kg} /$ min might prove helpful in preventing renal failure after cardiopulmonary bypass in children by increasing renal functional reserve.

Acknowledgments. The authors thank Mrs. M. Wyss, Mrs. L. Bockhorn, and Mrs. M. Lopez for technical assistance.

\section{REFERENCES}

1. Gray R, Shah PK, Singh B, Conklin C, Matloff JM 1981 Low cardiac output states after open heart surgery. Comparative hemodynamic effects of dobutamine, dopamine, and norepinephrine plus phentolamine. Chest 80:16-22

2. Hilberman M, Maseda J, Stinson EB, Derby GC, Spencer RJ, Miller DC, Oyer PE, Myers BD 1984 The diuretic properties of dopamine in patients after open-heart operation. Anesthesiology 61:489-494

3. Sato Y, Matsuzswa H, Eguchi S 1982 Comparative study of effects of adrenaline, dobutamine and dopamine on systemic hemodynamics and renal blood flow in patients following open heart surgery. Jpn Circ J 46:1059-1072

4. Mousdale S, Clyburn PA, Mackie AM, Groves ND, Rosen M 1988 Comparison of the effects of dopamine, dobutamine, and dopexamine upon renal blood flow: a study in normal healthy volunteers. Br J Clin Pharmacol 25:555-560

5. Chamberlain JH, Pepper JR, Yates AK 1980 Dobutamine, isoprenaline and dopamine in patients with open heart surgery. Catecholamines after openheart surgery. Intensive Care Med 7:5-10

6. Pelayo JC, Fildes RD, Jose PA 1984 Age-dependent renal effects of intrarenal dopamine infusion. Am J Physiol 247:R212-R216

7. Buckley NM, Charney AN, Brazeau P, Cabili S, Frasier ID 1981 Changes in cardiovascular and renal function during catecholamine infusions in developing swine. Am J Physiol 240:F276-F281

8. Buckley NM, Brazeau P, Frasier ID 1983 Cardiovascular effects of dopamine in developing swine. Biol Neonate 43:50-60

9. Lang P, Williams RG, Norwoo WI, Castaneda AR 19880 The hemodynamic effects of dopamine in infants after corrective cardiac surgery. J Pediatr 96:630-634

10. Bhat GJ, Gluck MD, Lowenstein J, Baldwin DS 1976 Renal failure after open heart surgery. Ann Intern Med 84:677-682

11. Bourgeois BF, Donath A, Paunier L, Rouge JC 1979 Effects of cardiac surgery on renal function in children. J Thorac Cardiovasc Surg 77:283-286

12. Chesney RW, Kaplan BS, Freedom RM, Haller JA, Drummond KN 1975 Acute renal failure; an important complication of cardiac surgery in infants. A Pediatr 87:381-388

13. Covitz W, Eubig C, Moore HV, Truman AT, Sellers BB, Shelnutt R, Hadden B 1984 Assessment of cardiac and renal function in children immediately after open-heart surgery: the significance of a reduced radionuclide ejection fraction (postoperative ejection fraction). Pediatr Cardiol 5:167-174

14. Abel RM, Buckley MJ, Austen WG, Barnett GO, Beck CH, Fischer JE 1976 Etiology, incidence, and prognosis of renal failure following cardiac operations. J Thorac Cardiovasc Surg 71:323-333

15. Baxter P, Rigby ML, Jones ODH, Loncoln C, Shinebourne EA 1985 Acute renal failure following cardiopulmonary bypass in children: results of treatment. Int J Cardiol 7:235-239

16. Zender R, Falbriard A 1966 Analyse colorimetétrique des cétohoxoses et de l'inuline par la réaction thiobarbiturique. Clin Chim Acta 13:246-250

17. Smith HW, Finkelstein N, Aliminosa L, Crawford B, Graber M 1945 The renal clearances of substituted hippuric acid derivatives and other aromaic acids in dog and man. J Clin Invest 24:233-404

18. Calcagno PL, Rubin MI 1963 Renal extraction of para-aminohippurate in infants and children. $J$ Clin Invest 42:1632-1639

19. McCrory WW 1972 Developmental Nephrology. Harvard University Press Cambridge, MA, p 96

20. Fiselier T, Monnens L, van Munster P, Jansen M, Peer P, Linen P 1984 The renin-angiotensin-aldosterone system in infancy and childhood in basal conditions and after stimulation. Eur J Pediatr 143:18-24

21. Lundberg S 1967 Renal function during anaesthesia and open-heart surgery in man. Acta Anaesthesiol Scand 27:1-82

22. Ichikawa I, Pfeffer JM, Pfeffer MA, Hostetter BM 1984 Role of angiotensin II in the altered renal function of congestive heart failure. Circ Res 44:669675

23. Carey RM, Thorner MO, Ortt EM 1980 Dopaminergic inhibition of metoclopramide-induced aldosterone secretion in man. J Clin Invest 66:10-18

24. Noth RH, McCallum RW, Contino C, Havelick J 1980 Tonic dopaminergic suppression of plasma aldosterone. J Clin Endocrinol Metab 51:64-69

25. Barrazzone C, Jaccard C, Berner M, Dayer P, Rouge JC, Oberhansli I, Friedli B 1988 Propanolol treatment in children with tetralogy of Fallot alters the response to Isoprenaline after surgical repair. Br Heart J 60:156-161

26. Schmidt M, Imbs JL 1980 Pharmacological characterization of renal vascular dopamine receptors. J Cardiovasc Pharmacol 2:595-605

27. Felder RA, Blecher M, Eisner GM, Jose PA 1984 Cortical tubular and glomerular dopamine receptors in the rat kidney. Am J Physiol 246:F557F568

28. Tulassay T, Seri I, Machay T, Kiszel J, Varga J, Csömör S 1983 Effects of dopamine on renal functions in premature neonates with respiratory distress syndrome. Int J Pediatr Nephrol 4:19:23 